\title{
Orthodox Christian Bulgarians Coping with Natural Disasters in the Pre-Modern Ottoman Balkans
}

\author{
Raymond Detrez
}

Citation: Detrez, Raymond. 2021. Orthodox Christian Bulgarians Coping with Natural Disasters in the Pre-Modern Ottoman Balkans. Religions 12: 367. https://doi.org/ $10.3390 /$ rel12050367

Academic Editor: Dennis Ioffe

Received: 30 April 2021

Accepted: 18 May 2021

Published: 20 May 2021

Publisher's Note: MDPI stays neutral with regard to jurisdictional claims in published maps and institutional affiliations.

Copyright: (C) 2021 by the author. Licensee MDPI, Basel, Switzerland. This article is an open access article distributed under the terms and conditions of the Creative Commons Attribution (CC BY) license (https:// creativecommons.org/licenses/by/ $4.0 /)$.
Department of Languages and Cultures, Ghent University, 9000 Ghent, Belgium; Raymond.Detrez@Ugent.be
Abstract: Premodern Ottoman society consisted of four major religious communities-Muslims, Orthodox Christians, Armenian Christians, and Jews; the Muslim and Christian communities also included various ethnic groups, as did Muslim Arabs and Turks, Orthodox Christian Bulgarians, Greeks, and Serbs who identified, in the first place, with their religious community and considered ethnic identity of secondary importance. Having lived together, albeit segregated within the borders of the Ottoman Empire, for centuries, Bulgarians and Turks to a large extent shared the same world view and moral value system and tended to react in a like manner to various events. The Bulgarian attitudes to natural disasters, on which this contribution focuses, apparently did not differ essentially from that of their Turkish neighbors. Both proceeded from the basic idea of God's providence lying behind these disasters. In spite of the (overwhelmingly Western) perception of Muslims being passive and fatalistic, the problem whether it was permitted to attempt to escape "God's wrath" was coped with in a similar way as well. However, in addition to a comparable religious mental make-up, social circumstances and administrative measures determining equally the life conditions of both religious communities seem to provide a more plausible explanation for these similarities than cross-cultural influences.

Keywords: Bulgarians; Orthodox Christianity; Islam; Ottoman Empire; natural disasters; plague

In this contribution, I intend to shed some light on how in the pre-modern era, religious beliefs determined the way Orthodox Christians-more specifically, Bulgarians in the Ottoman Balkans-coped with natural disasters. Under "pre-modern era in the Ottoman Balkans", I understand the period from the fifteenth through the early nineteenth centuries. In the fifteenth century, a long series of disasters, caused predominantly by the violent Ottoman conquest of the Balkans, had come to an end; in the late eighteenth century and fully in the nineteenth century, as a result of the spread of Enlightenment ideas, attitudes towards natural disasters gradually changed, acquiring a more rational, scientific character. The focus on the Bulgarians is justified by the fact that among the South Slavs, they were-next to the Greeks - the most representative part of the Orthodox Christian flock, administered by the Patriarchate of Constantinople. (The Serbs under Ottoman rule had, from 1557 to 1766, a patriarchate of their own and were more directly exposed to Western influences, originating from Venetian Dalmatia and, after the 1699 Treaty of Passarowitz, from the Habsburg lands.) Bulgarians, Greeks, Serbs, Vlachs, and others all together constituted what in Ottoman Turkish was called the Rum milleti-the millet (community) of the Rum (from Greek Rhomaios, "Roman", "Byzantine", whence "Orthodox Christian"), which in the Balkans from the late eighteenth century onwards largely coincided with the jurisdiction of the Patriarchate of Constantinople. The position of the Bulgarians and the other members of the Rum milleti in the Ottoman Empire was that of zimmis-beneficiaries of the zimma, the covenant between Muslim rulers and Christian and Jewish subjects, which guaranteed, for the "people of the Book [the Old and New Testament]", "protection in exchange for submission", or, as Braude and Lewis (1982, p. 3) phrased it more adequately, they were "discriminated against without being persecuted". 
In pre-modern times, in the Ottoman Balkans as elsewhere, ethnic belonging was far less important than it became after the rise of nationalism in the nineteenth century. The cultural environment in which the Balkan Orthodox Christians then lived and acted was not determined by ethnic but by religious identity, as the well-known terms referring to this environment-the "Byzantine commonwealth" (Obolensky 1971), "Slavia orthodoxa" (Picchio 1991)—suggest. Although, texts in Church Slavonic continued to be copied and occasionally new texts in that language were created. Greek, initially the liturgical and administrative language and the language of intellectual communication used by the Patriarchate of Constantinople, gradually developed into the common language of the entire Orthodox Christian community, replacing, especially in Bulgaria and Macedonia, Church Slavonic in all "high" functions excluded the merely liturgical. Only in the autonomous Serbian Patriarchate of Peć the Church Slavonic tradition was preserved.

Greek sources should be treated not necessarily as Greek sources (in an ethnic sense) but as "Orthodox Christian sources in Greek", pertaining to all Balkan Orthodox Christians of whatever ethnic appurtenance. One of the main sources, informing us about the Orthodox Christians' attitudes towards natural disasters, is the remarkable autobiographical chronicle, written in Greek by priest Synadinos (1600-1662), who lived and worked in the multiethnic and multiconfessional city of Serres in Northern Greece (Odorico and Asdrachas 1996, with French translation and copious comments). The "Christians" (christianoi) whom Synadinos systematically refers to are not only Greeks but also Slavs, Vlachs and others. Some of these Christians bear indisputably Slavic names like "Petkos" and "Asanis" (Bulgarian Petko and Asen or Asan). (Odorico and Asdrachas 1996, pp. 96, 102, 176).

In spite of the religious discrimination non-Muslims in the Ottoman Empire were subject to, everyday living conditions of ordinary Christians, Muslims and Jews did not essentially differ. Most of them were raja, "flock" guided and guarded by askeri or representatives of the sultan, as the Ottoman vision on the state had it. Inevitably, the shared life conditions in the Ottoman Empire and the age-long cultural interaction of the three creeds produced many instances of syncretism and similar ways of dealing with the fortunes of life.

Having sketched the societal framework in which they lived and acted, I now proceed to the examination of how Bulgarians - and by extension all Orthodox Christians - in the pre-modern Ottoman Empire dealt with natural disasters and how their attitudes were determined by religious beliefs. A discussion of the similarities and dissimilarities between the attitudes of Christian Bulgarians and Muslim Turks, from a genuinely "Balkanistic" standpoint, will shed an additional light on Bulgarian popular religiosity.

The events people perceived as "disasters" are summed up exhaustively by Synadinos. In addition to the disasters caused by humans (as wars, plunders, massive executions and suchlike), Synadinos points out "epidemics and arsons (...), earthquakes, thunder, lightning (...), starvation and hailstorm (...), wild animals pillaging what little we have" (Odorico and Asdrachas 1996, p. 225). Only floods and volcanic eruptions are missing from his list of calamities. Sources mentioning the occurrence of these natural disastersmarginalia (notes written in the margin of a text), chronicles, sicils (Ottoman legal or cadastral records), observations by Western travelers and diplomats to the Orient-are relatively numerous. Extremely scarce, however, are those that provide us with more than laconic and commonplace information about the people's reactions to these disasters. The marginalia mention the exact date and even the hour earthquakes occurred-unfortunately often omitting the location-but mostly in a stereotypical, "telegraphic" style-as in the following Bulgarian examples, borrowed from Gradeva (1999, p. 58; quoting Načev and Fermendžiev 1984, p. 97):

Be it known when the earth quaked in the year 7195 [=1678], [in] the month of October, 23rd day.

[Be it known] when the earth quaked in the year 1738, in May, at noon. There was a fair in Svishtov at that time.

Human emotions are paid attention to in a lapidarian way: 
31 May 1738. At 3 a.m. there was a powerful earthquake. The frightened people ran back and forth but clinging to each other, so that nothing befell them. After three hours it occurred again, this time weaker.

While the toll of human lives is not always specified, the material damages are often listed up at length, with a focus on the cult buildings. Thus, priest Jovčo from Trjavna describes in his chronicle the sad results of an earthquake in Bucharest in 1802, where he spent some time as a student in a Greek school:

In the same year, in the month of 14 October, the earth quaked severely, in villages and towns, many houses were demolished, also the mosques in the towns fell, and everywhere; in Bucharest the tower [Colţea, RD], the tallest belfry of the Church of the Three Hierarchs, fell too. And many other churches fell. The two domes of the Church of Saint George fell, and the belfry was also damaged, and there is a plane between the metropolitanate and Domna Valasha [the Church of Domnița Bălașa, RD] in front of the house of Brancoveanu, and a lot of boiling water sprang from the earth; and also in Moldavia many houses and churches were damaged. And the Monastery of the Three Hierarchs, where the relics of the Venerable Paraskevas [Paraskeva, RD] are laid, was also damaged and the belfry fell and was razed to its foundations (Gradeva 1999, p. 59; quoting Načev and Fermendžiev 1984, p. 291)

The lack of interest in human casualties might be explained by the triviality of death in a society with a high mortality and an understanding of human existence focused on afterlife rather than life. The special attention paid to the damaged churches and monasteries obviously resulted from their religious relevance, but there might also be a more prosaic explanation: the costly, complicated and long-running legal procedures which the Ottoman authorities imposed whenever non-Muslim cult buildings had to be restored. Applications for a building permit, decisions about possible tax reductions and other measures taken by the authorities were registered in sicils, records of rulings by local kadis (Islamic judges) (Gradeva 1999, pp. 61-63). Evidently, neither of these formalized administrative documents took into consideration the attitudes and feelings of the applicants.

In spite of the lack of detailed information, even a cursory glance at the available documents reveals that to the inhabitants of the Balkan Peninsula during the period in question, every accident-small or huge, individual or collective-was interpreted by all religious communities as a token of the God's providence. God's involvement may be active, when the disaster is understood as a punishment-gněv božij (God's wrath), grěh radi naših (because of our sins). A Bulgarian priest noticed:

And be it known that there was a tremendous earthquake, the fear of God. And the earth and the buildings trembled from the fear of God. It was in the year 1781. The month of March, the fourth day, the sixth hour in the middle of the day. (Načev and Fermendžiev 1984, p. 111)

An other Bulgarian chronicler ascribes two locust plagues to God's wrath:

And God sent His wrath onto His creatures from Zagore to the Danube, He sent locusts. It was in the year 1690. And God sent His wrath a second time--He sent locusts in the year 1711 ( . . . ). (Načev and Fermendžiev 1984, p. 90)

In 1713, a Serbian chronicler mentions that "at that time it happened that through God's will (hotěnijem božije [sic]) lightning struck a mosque and destroyed it completely" (Stojanović 1903, p. 87). However, God also intervenes in individual tribulations, as in the case of a father who opposed his daughter to become a nun, "but due to God's command (s božie povelenie) he was not able to do anything" (Načev and Fermendžiev 1984, p. 106). Some catastrophes seem to have occurred only by God passively consenting to them (božijem popuštenijem). In this case too, however, His role was considered to be decisive. As Hans-Georg Beck (1978, p. 263) remarks, "Physisches Übel lässt nach ihrer Lehre [the orthodox theology, RD] Gott nur zu, um damit höhere Zwecke zu erreichen, 
Strafe für Sünde, Prüfung, Hinwendung weg von der Materie zu geistigen Werten usw". When a catastrophe has an evident, understandable and explainable cause and there is no clear reason for the necessity of divine intervention, it may also be ascribed to the devil. Synadinos thinks that both Manolis being hit by a stone at the head and becoming deaf, and Vasilis breaking his leg after he is knocked down by a horse, are due to "a temptation by the devil" (diavolou peirasmos), all the more so as in both cases the complications turned out to be fatal. (Odorico and Asdrachas 1996, pp. 71, 114) Although he is perfectly aware of the exact causes of the fire in the čaršija (business district) of Serres in 1630, Synadinos nevertheless blames it on the devil:

In September, on Sunday 30 at daybreak, the workshops were burning and the fire started from the workshops of the cotton-workers. In the workshop of the shoemakers some people drank and smoked, and passing by, they beat out their pipes, the fire in them not being extinguished, while the workshop was filled with bales of cotton. And - temptation by the devil—the fire reached the cotton and the entire workshop was set ablaze. And all the cotton-workers' workshops were burning. (Odorico and Asdrachas 1996, p. 108)

Ultimately, the entire čaršija burned to ashes, a catastrophe the city hardly recovered from. A Serbian chronicle attributed the long and devastating Austro-Turkish war, which started in 1683, as a combination of "a devilish scheme" (djavolsko navaždenije) and "God's consent because of our sins" (božije popuštenije greh radi naših) (Stojanović 1902, p. 431).

The most devastating catastrophes—earthquakes and epidemics—occurred with such a high frequency that they must have been felt as a part of "daily life". Manolova-Nikolova (2004) counts 49 outbreaks of the plague (pp. 63-65) and 24 earthquakes (pp. 49-50) in Bulgaria in the eighteenth century alone. Although they were often preceded by omens as solar eclipses or the appearance of comets, earthquakes happened unexpectedly and momentarily and could not be prevented or remedied. During an earthquake, there was no time for deliberation, and running away was considered a natural and acceptable reaction. Epidemics were of a different nature; they could be observed and reflected upon during their appearance and the reaction to them was the result of ample consideration.

The usual words for "epidemic" were mor (in Bulgarian), mora in Serbian, thanatiko in Greek, which all mean "death" or "lethality". In most cases, the epidemic referred to was pestilence (čuma), which as a rule, though not always, was more or less clearly distinguished from other epidemics as smallpox or malaria. (Manolova-Nikolova 2004, pp. 170-71) Smallpox, however, which struck mainly children and was never that lethal, was not considered as a divine punishment, but rather as a "mécanisme de selection naturelle divine" (Kostis 1996, p. 584). The plague, on the other hand, spread rapidly and massively among all generations and made people die in painful agony. Synadinos's autobiography ends with an impressive description of the plague in his native Serres in 1641:

The same year, from September onward and during the entire winter and the entire summer, the was a huge epidemic among all people in the entire world and it spread all over Egypt, Anatolia, Bursa, Constantinople, the islands, Rumelia, Thessaly, Thessalonica, Serbia, Bulgaria, Phillipopolis, Melnik, Siderokastron, Drama, Zich-nokhoria, and Serres, and it spared neither cities nor villages, not a single house, and no one among the elderly people could recall an epidemic that spread over such a large space. And wherever death arrived, it reaped everyone and even if one single person escaped, there was no single house that was spared. And the plague was so devastating that no one caught by it could escape, and it reaped people so quickly that they suffered no more than one or two days, sometimes, rarely, a week, and of a hundred of sick only one recovered. And how many Turks, Christians, Jews, and Gypsies in Serres died, about 12,000. At the same time as the plague also scabies and eye diseases spread. That year a great curse struck the people. (Odorico and Asdrachas 1996, pp. 169-71) 
Like other writers of autobiographies, chronicles and marginalia at that time, Synadinos explicitly points out here that members of all religious communities fell victim to the plague. Synadinos's use of the overarching term "Christians" for people of various ethnic origins is typical of the Balkans in the pre-modern (pre-national) era. As we already mentioned, being an Orthodox Christian, a Catholic, an Armenian, a Jew, or a Muslim was far more important than belonging to some ethnic group. Religious belonging was of particular relevance also in relation to the natural disasters: punishing the sinners, God was believed to discriminate between the various kinds of believers. Synadinos points out that the plague killed more Turks (which means "Muslims") than Christians.

And during winter many Turks died, but not so many Christians, and the Turks were amazed and all those that did not understand, said: "The Christians apply some sorcery in order not to die and they threw the evil upon the Turks and that is why they die." ( . . ) And during winter the Christians did not die, but in May, June and July many of them died, but the Turks died all year long in great numbers. (Odorico and Asdrachas 1996, p. 175)

In 1725, an anonymous Bulgarian author wrote that "[i]n that good winter began a bad disease, its name is the plague. From October onward, it killed only a few Christians, but Turks all the time" (Načev and Fermendžiev 1984, p. 83). Although these authors do not explicitly claim that God punishes non-Orthodox Christians more severely than Orthodox Christians, it is clearly implied. Throughout the ages following the Great Schism in 1054, Orthodox Christians believed God to be particularly resentful of the Catholics. Partenij Pavlovič (ca. 1700-1760), a highly educated Bulgarian cleric who spent his life in Serbia, did not hesitate to ascribe three major disasters that happened during his lifetime to Catholic outrages against Orthodox Christians:

I think that the Gracious God in our times too, as He destroyed the ancient city of Nineveh, so did He destroy now Lisbon, the glorious city in Portugal, because they chased away our faith and tortured our Orthodox Christians, as I heard from some that immigrants and foreigners are cruelly tortured. And this city was destroyed in 1755, on December 1, just before noon.

Some years ago, in the Hungarian city of Buda, they wanted to create a Roman altar in one of our Orthodox churches. Through the wrath of God, the gunpowder beneath the city exploded and provoked an earthquake, and all people started fleeing far away out of fear for the fiery ignitions and the thundering of the canons.

In the glorious Venetian city of Corfu in 1719, the same happened. The entire palace of the general was destroyed by thunder and fire because he wanted to make a Latin altar in a church of the Orthodox Christians, in which the holy relics of our Holy Father Spyridon of Trimythous the Wonderworker rest (Angelov 1964, p. 206).

The eagerness with which the writers of the marginalia sum up the number of collapsed mosques may also be inspired by the idea that God preferably punishes nonOrthodox Christians. However, the fact that in all Ottoman cities, mosques were the highest and therefore the most vulnerable constructions is probably a more trustworthy explanation.

Although God's wrath apparently strikes entire communities, "because of their sins", nevertheless each case of disease or death is considered to be individual. The Byzantines made a distinction between God's providence "in general" and individual "fate" (tychē), a concept inherited from antiquity. Tyche corresponds to Bulgarian "sădba" or kăsmet (from Turkish klsmet) and Serbian "sudbina". In times of plague, some people do not fall ill, others fall ill but recover, and still others die-each case a question of sădba. Byzantine theologians had not been able to completely remove the contradiction that obviously exists between "fate" and "divine providence" (Beck 1978, pp. 271-73). Synadinos, for his part, strongly keeps to a relation between (individual) "sin" and "divine punishment" to explain the seeming arbitrariness of God's providence: "[God\} does not punish us because of the sins of others, but when a man commits a sin, it is him whom God punishes." (Odorico and 
Asdrachas 1996, p. 180). For some victims of the plague, Synadinos suggests some rather far-fetched reasons for their death. Priest Georgis, who died after being infected when burying the dead, allegedly had the unpleasant habit to take revenge for insults during the liturgy, and "maybe that is the reason why God deprived him of his life" (Odorico and Asdrachas 1996, p. 178). About a deceased female roe vendor, he points out that "as we have heard everyone telling, she was not that innocent. (...) Maybe God took her life for that reason" (Odorico and Asdrachas 1996, p. 180).

Conversely, those who escaped death also did so as a result of divine intervention. Western travelers in the Balkans love to comment on the-in their opinion-radically different attitudes of Christians and Muslims towards natural disasters-a distinction that, curiously enough, is seldom commented on in the Slavic or Greek sources. Muslims are alleged to fatalistically accept the plague as sent by God, finding comfort in the idea of individual predestination: they believed that one's lifetime was completely determined by God's providence or "written on the forehead". "I had two notable examples", writes Sir Henry Blount (1602-1682), an English landowner and traveler, in 1636,

one was at Rhodes, where just as we entered the Port, a French Lacquey of our company died with a great plague for which he had taken from the Gunners Mate, who with one running upon him, conversed and slept among us: The rest was so far from fear, at his death, as they sate presently eating, and drinking, by him, and within half an hour, after his removal, slept on his Blanquet, with his clothes instead of a Pillow, which when I advised them not to do, they pointed upon their foreheads, telling me it was written there at their birth when they should die; they escaped, yet divers of the passengers thereof before we got to Egypt: The other was at my passage to Adrianople in Thrace, myself, the Ianizary, and one other being in a Coach, we passed by a man in good quality, and a Soldier, who lying along, with his Horse by, could hardly speak so much, as to intreat us to take him into Coach; the Ianizary made our companion ride his Horse, taking the man in; whose breast being open, and full of plague tokens, I would not have him received; but he in like manner, pointing to his own forehead, and mine, and told me we could not take hurt, unless it were written there, and that then we could not avoid it; the fellow died in the night ( ... ) (Blount 1636, pp. 85-86)

The Greek historian Kostas Kostis (1996, p. 585) remarks that “[1]es textes du XVIIIe et des débuts du XIXe siècle, abondent en commentaires moqueurs des voyageurs occidentaux, qui, du haut de leur supériorité, accusent les Musulmans d'attitude fataliste envers la peste et critiquent leur immobilité dans les lieux touchés par l'épidemie". Particularly revealing is the observation made by the French traveler (of Hungarian origin) Baron François de Tott (1733-1793) in his Mémoires sur les Turcs et les Tartares in 1785 . He notices that "les Turcs trouvent encore dans une aveugle prédestination une plus grande sécurité". "Exempts de l'excès du meme préjugé, les Grecs [the Orthodox Christians, $\mathrm{RD}]$, les Arméniens, les Juifs ont étudié une sorte de remède dont ils paraissent user avec une espèce de success". However, "[l]es Européens sont les seuls qui prennent quelques précautions contre la contagion" (Tott 1785, vol. I, pp. 30-31). Tott's observation perfectly fits into Maria Todorova's concept of "Balkanism", a set of biased perceptions of the Balkan peoples attributing them a particular mental make-up that culturally locates them permanently "in-between" the Orient, "les Turcs", and the West, "les Européens", and makes them "semi-European", "semi-Asian". (Todorova [1997] 2009) Ironically, the fatalistic Ottomans were familiar with vaccination already in the early eighteenth century, before it found its way to Western Europe. The English Lady Mary Wortley Montagu described the procedure in 1718 in one of her letters from Istanbul: "The smallpox, so fatal and so general amongst us, is here entirely harmless by the invention of engrafting [which is the term they give it]. ( . . ) Every year thousands undergo this operation ( . . ) There is no example of anyone who has died in it (... )" (Montagu 1988, p. 121).

A closer look reveals that Christians and Muslims facing the plague actually behaved in a rather similar way. In some cases, the ill were isolated, visitors were put into quarantine 
and massive religious gatherings were prohibited, albeit mostly to little avail (Panzac 1985, pp. 298-99). Both religious communities, however, considered collective and continuous praying as the most effective way to cope with the epidemic. In the eighteenth century, after being introduced in the Peloponnesus and the Aegean Islands, Saint Haralampij enjoyed an increasing popularity in Bulgaria and Serbia as a protector against the plague, as the mushrooming vitae, icons and special liturgies, dedicated to the saint, indicate (Manolova-Nikolova 2004, pp. 121-67). His feast day on February 10 was called Čuminden, "day of the plague", in Bulgaria. A curious phenomenon, probably occurring rarely but typical of Ottoman multiconfessional society, was the shared praying sessions between Christians and Muslims. Manolova-Nikolova (2004, pp. 159, 182) quotes a Catholic priest in Trănčovica in North Bulgaria, where in 1806 a kind of "prophet" appealed to "all priests, to whatever sect they belonged" to bring a sacrifice to "the goddess Plague". "Catholics, schismatics [Orthodox Christians, to the Catholic author, RD] and Turks [Muslims, RD] came in droves to hear the old inspirer". As with many other cases of religious syncretism in the Balkans, this one too seems to have pagan roots: the personification of the plague as an evil spirit-a veštica (witch) in Bulgarian, a cin (demon) in Turkish. (Panzac 1985, p. 291)

Both Muslims and Orthodox Christians struggled with the problem to what extent it was permitted to oppose the Lord's will by attempting to escape His wrath. Was it allowed to flee the location where the plague had spread in order to avoid contagion? Within the Islamic community, this problem had sporadically been discussed since the time of Mohammed already. (Dols 1977, pp. 22-25). It became topical in the middle of the fourteenth century, after the Black Death had made millions of victims in the Middle East and Europe. Ibn Hajar al-Asqalani (1372-1449), referring to the Hadith, recommended not to flee from the plague, but also not to enter regions struck by it. Other Islamic theologians, the most influential among them being Jalal al-Din al-Suyuti (1445-1505), denied that the disease was transmitted from one person to another (the role of rats and fleas was not yet known), but that it spread through miasmas (poisonous bad air). The fact that everyone came in contact with the miasmas but not everyone was infected and not everyone who was infected died was explained by God's will. Al-Suyuti added that not only to die from the plague but also to recover from it was of equal worth as dying as a şehit, a martyr fighting for the faith (Ayalon 2015, p. 26; Manolova-Nikolova 2004, pp. 179-80; Panzac 1985, pp. 282, 290).

The Ottomans adopted the same principles but tended nevertheless to be more tolerant towards flight. The learned Taşköprüzade Ahmed (1495-1561) and șeyh ül-islām Ebussuud Efendi (1490-1574) were of the opinion that flight in certain circumstances was allowed (Ayalon 2015, p. 76; Varlik 2008, pp. 172-76, 202-4). Elias Abesci, an English servant at the sultan's court, wrote in his description of the Ottoman Empire (published in French):

Tant que ce précepte du Koran est resté sans commentaire, les Turcs y ont adhéré constamment à la lettre; mais un jour un Mufti moins superstitieux que ses prédécesseurs, a trouvé, dans ce meme livre sacré, un passage, qui, à l'aide de quelque petit supplément, interprête ainsi le premier. Quoiqu'il soit indubitable qu'un homme ne doit tenter de contrarier la volonté de Dieu, il peut cependant en cas de peste ou dans toute autre maladie contagieuse dans la ville, en sortir, pourvu qu'il ne s'en éloigne pas à une plus grande distance de six lieues. (Abesci 1792, vol. II, p. 223)

Anyhow, not fleeing was not a question of mere fatalism. It was also considered a holy duty to take care of ill relatives and to bury the deceased according to the religious prescriptions. In the patriarchal Muslim community, these duties were strong imperatives not to flee. (Panzac 1985, pp. 283-84)

At first sight, Orthodox Christians seem to have fled for the plague without any qualms, although to them too the duty to look after the ill and the dead was a serious reason to stay (Manolova-Nikolova 2004, p. 171). However, this permissive attitude towards fleeing for the plague was relatively new. Just like the Muslims, the Christians 
thought that the epidemic spread through miasmas with which all people got in touch, but not all died. "Donc, les causes de la mort ne se trouvent pas dans le phénomène physique, c'est-à-dire la maladie pestilentielle, mais bien ailleurs, dans 'le terme de la vie qui est atteint'"(Kostis 1996, p. 589). Because the end of one's life was predestined, running away had no sense. Theophanes of Medeia (1400-1474) had advised that "il ne faut pas partir vers des lieux déserts ni meme chercher des vents, mais se réfugier vers Dieu, celui qui peut sauver tous ceux qui s'adressent à Lui" (Kostis 1996, p. 590). Christian tolerance towards those who flee for the plague, combined with an outspoken preference for abiding by God's providence by staying and hoping for divine protection, clearly transpire from the following passage from the Chronicle of the Monastery of Trojan in Bulgaria:

And again in the that year 1837 there was a great lethal disease among the people, which is called the plague; it was all over the universe and many people and children, and countless women died, not only Christians, but also infidel Turks and Jews; and people ran away from the towns and the villages hiding from the plague in the vineyards, but there they died just the same. Others fled to the monastery, and came to God's monastery, to hide under its roof. People from Loveč and Sopot fled [to the monastery, RD].

Additionally, when the feast day of the Dormition of the Mother of God had come, the notables that were in the monastery gathered and consulted with the abbot, and they promised to give him money if he did not allow visiting pilgrims on the feast day [to enter the monastery, RD] and to infect the healthy, and if he closed the gates, so that ill and infected people could not enter.

"But the abbot", Mister Partenij replied, "I cannot do that, my children, I cannot close the gates, because these our brothers and Christians run away to the monastery and to us out of need as well—some in order to confess, others to partake in the holy sacraments. How can I send them away without letting them participate in the communion. But do not be afraid, put your hope on the Mother of God, pray to Her incessantly and do not be afraid. Among them some retired to the cabins [in the neighborhood of the monastery, RD], others remained in the monastery and the abbot gathered the monks and convinced them to stay and to make preparations for the feast day and the vigils as usual. Those among the brothers that were disposed to obedience, remained, others did not obey and ran away to the woods. And those who were obedient and remained in the monastery and put their hope on the Most Holy Mother of God were saved by Her from the lethal ulcer. And those who ran away from the monastery perished. The Mother of God accomplished a great miracle, to the astonishment of all. The brothers that remained in the monastery welcomed the pilgrims and served them. There were pilgrims who were infected and fallen ill from that cruel ulcer, but no one died. This happened because the abbot, Mister Partenij, and the other brothers in the holy monastery devoted themselves to prayer and vigils and the Mother of God protected them and gave health and life to all those that were under Her canopy and She saved them from the cruel ulcer" (Načev and Fermendžiev 1984, pp. 281-82).

Although advised against by Christians and disapproved of by Muslims, flight was resorted to by both communities. However, the decision to flee or not depended not only on religious considerations. Administrative measures and social circumstances seem to have been important factors as well. According to Sam White (2011, p. 89; quoted by Ayalon 2015, p. 79), most Ottoman subjects remained where they were "not because flight violated divine law, but because it violated imperial law". Flight created chaos and allowed people to avoid paying taxes. Before leaving, they had to fulfill their financial and fiscal obligations (Manolova-Nikolova 2004, p. 176). In addition, one's social position played a significant role too. Well-to-do citizens, who could isolate themselves in huge mansions enclosed by gardens and walls usually preferred to remain, also to prevent their properties from being robbed. On the other hand, if they possessed a house in the countryside, which was often the case, they could find shelter there. As a rule, poor city-dwellers for financial reasons preferred not to leave their working places and few belongings (Ayalon 2015, pp. 156-57). In general, peasants were more inclined to flee and, doing so, 
displayed a greater solidarity and mutual support than the more individualistically minded city-dwellers (Manolova-Nikolova 2004, pp. 176-77). M. Mičev (1964) describes the case of the inhabitants of 42 Bulgarian villages in the region of Vraca, north of Sofia, who in $1762-$ 1763 fled for the plague. The inhabitants of four of these villages found shelter in a cave; others built temporary accommodations in the neighborhood of their native village and returned to it after the plague had come to an end; still others transformed their temporary accommodations into new, lasting settlements. According to the Bulgarian historian Hristo Gandev (1976, pp. 539-32), the behavior of Christians and Muslims was so divergent that it resulted not only in the foundation of new villages but also in a demographic shift, whereby Christian Bulgarians in the cities became a majority at the expense of the Turkish Muslims, with dramatic political consequences during the national revival period. However, such resettlements occurred also among the Turkish population. Manolova-Nikolova (2004, p. 181) mentions the names of about a dozen of villages in Bulgaria that were left by Turks and/or Pomaks (Bulgarian speaking Muslims) after an outbreak of the plague. According to Manolova-Nikolova, they did so under the influence of the Christian practice.

One should not think of flight too much as a rational solution, made in disregard of religious prescriptions. Lady Montagu, describing the opening of the veins during "engrafting" (vaccination), relates that "[t]he Grecians have commonly the superstition of opening one in the middle of the forehead, in each arm, and on the breast to mark to sign of the cross" (Montagu 1988, p. 121). Obviously, even remedies based on empirical evidence needed some religious substantiation. Fleeing should not be merely tolerated or permitted by God but somehow required by God Himself. This idea is expressed in the margin of a Bulgarian liturgical book from 1725, saying that "whoever says 'I do not fear the plague' be accursed by God". (Načev and Fermendžiev 1984, p. 93) An elaborate "theological" justification offers Synadinos:

Because when you stay and do not try to escape, you display in front of God the attitude of one who did not fail and does not fear Him (...) It is fair and fitting to escape from his just wrath, as the prophet Isaiah has ordered: "My child, enter your chambers, and shut your doors behind you; hide yourselves for a little while until the fury has passed by." The words of the prophet make clear that you should escape without hesitation, not at your place, but in a hidden place where the wrath of God cannot find you. (Odorico and Asdrachas 1996, p. 233)

Muslims in Hejaz came up-“non sans humour", according to Panzac, quoting a letter by Johann Ludwig Burckhardt—with an other excuse to justify their fleeing from the plague:

Je vis alors qu'un grand nombre d'habitants fuyaient vers la montagne. Lorsqu'on leur demandait pourquoi ils avaient peur, puisque si leur destin était de mourir, la mort irait aussi les chercher sur la montagne, ils répliquaient: 'La peste est une grâce, qu'Allah a envoyé sur la terre, afin d'appeler rapidement au ciel les hommes vertueux. Nous sentons que nous ne sommes pas encore digne de cette grâce et nous nous en écartons jusqu'à d'autres temps. (Panzac 1985, p. 286)

To twenty-first century readers, these justifications probably sound rather casuistic. However, as Lucien Febvre ([1942] 1947) demonstrated in relation to Rabelais and his contemporaries in sixteenth-century France, people in the pre-modern world were incapable of reasoning The authors declare no conflict of interest outside of religion. To the Bulgarians in the Ottoman Balkans too, life was permeated by religion, all phenomena had a spiritual meaning and all actions needed a religious justification. They could think but in religious categories, according to an unshakeable religious logic.

Funding: This research received no external funding.

Institutional Review Board Statement: Not applicable.

Informed Consent Statement: Not applicable. 
Data Availability Statement: The study does not report any data.

Conflicts of Interest: The author declares no conflict of interest.

\section{References}

Abesci, Elias. 1792. État present de l'Empire Ottoman. I-II. Paris: Villette.

Angelov, Bonju. 1964. Săvremennici na Paisij II [Contemporaries of Paisij II]. Sofia: BAN.

Ayalon, Yaron. 2015. Natural Disasters in the Ottoman Empire. Plague, Famine, and Other Misfortunes. New York: Cambridge University Press.

Beck, Hans-Georg. 1978. Das byzantische Jahrtausend. München: Beck.

Blount, Henry. 1636. A Voyage into the Levant. A Breife (sic) Relation of a Journey, Lately Performed by Master H. B.( ... ). London: Andrew Crooke.

Braude, Benjamin, and Bernard Lewis. 1982. Christians and Jews in the Ottoman Empire: The Functioning of a Plural Society. London and New York: Holmes \& Meier.

Dols, Michael. 1977. The Black Death in the Middle East. Princeton: Princeton University Press.

Febvre, Lucien. 1947. Le problème de l'incroyance au 16e siècle: la religion de Rabelais. Paris: Albin Michel. First published 1942.

Gandev, Hristo. 1976. Problemi na bălgarskoto văzraždane [Problems of the Bulgarian National Revival]. Sofia: Nauka i izkustvo.

Gradeva, Rossitsa. 1999. Ottoman and Bulgarian Sources on Earthquakes in Central Balkan Lands (17th-18th Centuries). In Natural Disasters in the Ottoman Empire. Edited by Elizabeth Zachariadou. Rethymnon: Crete University Press, pp. 55-66.

Kostis, Kostas. 1996. La peste n'est pas une mort naturelle, mais un châtiment de Dieu. In Conseils et mémoires de Synadinos, prêtre de Serrès en Macédoine (XVIIe siécle). Edited by Paolo Odorico and Synadinos. Paris: Association “Pierre Belon”, pp. 581-96.

Manolova-Nikolova, Nadja. 2004. Čumavite vremena 1700-1850 [Times of Pestilence 1700-1850]. Sofia: IF-94.

Mičev, M. 1964. Vremenni razselvanija ili premestvane na njakoi selišta văv Vračansko prez XVIII v. poradi čumna epidemija [Temporary resettlement or relocation of some villages in the region of Vraca during the eighteenth century because of the plague]. Izvestija na etnografskija institut i muzej 8: 25-44.

Montagu, Lady Mary Wortley. 1988. Embassy to Constantinople. The Travels of Lady Wortley Monagu. London: Century.

Načev, Venceslav, and Nikola Fermendžiev, eds. 1984. Pisahme da se znae. Pripiski i le-topisi [We Wrote So That It Be Known. Marginalia and Chronicles]. Sofia: Otečestven front.

Obolensky, Dimitri. 1971. The Byzantine Commonwealth: Eastern Europe, 500-1453. London: Weidenfeld \& Nicolson.

Odorico, Paolo, and Spyros I. Asdrachas, eds. 1996. Conseils et mémoires de Synadinos, prêtre de Serrès en Macédoine (XVIIe siècle). Paris: Association "Pierre Belon".

Panzac, Daniel. 1985. La Peste dans l'Empire Ottoman 1700-1860. Leuven: Peeters.

Picchio, Riccardo. 1991. Letteratura della Slavia ortodossa: IX-XVIII sec. Bari: Dedalo.

Stojanović, Ljubomir. 1902. Stari srpski zapisi i nadpisi I [Old Serbian Marginalia and Inscriptions I]. Beograd: Državna štamparija.

Stojanović, Ljubomir. 1903. Stari srpski zapisi i nadpisi II [Old Serbian Marginalia and Inscriptions II]. Beograd: Državna štamparija.

Todorova, Maria. 2009. Imagining the Balkans. New York: Oxford University Press. First published 1997.

Tott, François de. 1785. Mémoires de Baron de Tott sur les Turcs et les Tartares. I. Amsterdam.

Varlık, Nükhet. 2008. Disease and Empire: A History of Plague Epidemics in the Early Modern Ottoman Empire (1453-1600). Ph.D. dissertation, University of Chicago, Chicago, IL, USA.

White, Sam. 2011. The Climate of Rebellion in the Early Modern Ottoman Empire. New York: Cambridge University Press. 